University of Nebraska - Lincoln

DigitalCommons@University of Nebraska - Lincoln

Faculty Publications: Department of Entomology

Entomology, Department of

August 1982

\title{
Host Range of Southern Corn Billbug (Coleoptera: Curculionidae) Adults and Larvae
}

\author{
Robert J. Wright \\ University of Nebraska-Lincoln, rwright2@unl.edu \\ J. W. Van Duyn \\ North Carolina State University \\ J. R. Bradley Jr. \\ North Carolina State University
}

Follow this and additional works at: https://digitalcommons.unl.edu/entomologyfacpub

Part of the Entomology Commons

Wright, Robert J.; Van Duyn, J. W.; and Bradley, J. R. Jr., "Host Range of Southern Corn Billbug (Coleoptera: Curculionidae) Adults and Larvae" (1982). Faculty Publications: Department of Entomology. 101.

https://digitalcommons.unl.edu/entomologyfacpub/101

This Article is brought to you for free and open access by the Entomology, Department of at DigitalCommons@University of Nebraska - Lincoln. It has been accepted for inclusion in Faculty Publications: Department of Entomology by an authorized administrator of DigitalCommons@University of Nebraska - Lincoln. 


\title{
Host Range of Southern Corn Billbug' (Coleoptera: Curculionidae) Adults and Larvae ${ }^{2}$
}

\author{
R. J. WRIGHT, ${ }^{3}$ J. W. VAN DUYN, AND J. R. BRADLEY, JR. \\ Department of Entomology, North Carolina State University, Raleigh, North Carolina 27650
}

ABSTRACT

Environ. Entomol. 11: 954-957 (1982)

Host range of the southern corn billbug, (SCB), Sphenophorus callosus (Olivier) (Coleoptera: Curculionidae), was tested with 14 crop and weed species by artificially infesting plants with SCB adults and eggs; field observations were also made. Of 14 species tested, only corn, Zea mays L., and yellow nutsedge, Cyperus esculentus L., allowed completion of larval development, although adults fed on a wider variety of plants. Scirpus cyperinus (L.) Kunth (Cyperaceae) was found to be a new SCB larval host from field observations. Overwintered SCB adults were fed sections of greenhouse-grown corn and four weed species in the laboratory. Survival was highest on corn and yellow nutsedge and lowest on common lambsquarters, Chenopodium album L. SCB were able to produce mature eggs only if fed either corn or yellow nutsedge.

Many Sphenophorus spp. weevils are economic pests of grass crops (Satterthwait 1932). One species, S. callosus (Olivier), the southern corn billbug (SCB), is an important pest of corn in eastern North Carolina. Webster (1912), Metcalf (1917) and Satterthwait (1931) listed nine genera ( 24 species) of Graminae, Cyperaceae, and Juncaceae as hosts of SCB.

Because of the restricted host range of SCB and its sedentary habits, early workers (Webster 1912, Metcalf 1917) suggested crop rotation as a control measure. However, since that time, the eastern North Carolina agroecosystem has changed greatly with respect to crop and weed species. This study was conducted to provide more information on the host range of adult and larval SCB in the current corn-soybean agroecosystem of eastern North Carolina so that the basis for continued use of crop rotation as a management tactic could be evaluated.

\section{Materials and Methods Adult and Larval Host Range}

During field studies of SCB biology from 1978 to 1980 , observations were made on SCB adult feeding habits in over 15 commercial corn fields (principally in Washington, Tyrrell and Hyde Counties, N.C.). Plant species on which adults were seen feeding were inspected later for SCB eggs and larvae.

Various grasses, sedges, rushes and related plants growing in drainage canals and uncultivated areas near the above infestations of SCB were sampled in late July to August; the period of greatest abundance of SCB pupae and teneral adults (Wright 1981). Specimens collected were preserved in alcohol or reared to adult emergence. Samples of weevil-infested plants were identified.

Studies were conducted at the Tidewater Research Station (TRS), Plymouth, N.C., in 1978 to 1980 to determine the acceptability of various plants for SCB adult

${ }^{1}$ Sphenophorus callosus (Olivier). Voucher specimens of adults are deposited with the NCSU Dept. of Entomology Collection.

2Received for publication 13 November 1981 . Paper no. 8076 of the Journal ${ }^{2}$ Received for publication 13 November 1981. Paper
eries of the N.C. Agric. Res. Serv., Raleigh, NC 27650.

${ }^{3}$ Present address: Cornell University, Long Island Horticultural Research Lab, 39 Sound Avenue, Riverhead, NY 11901. feeding and larval development. Plants chosen were crops or weeds common in the eastern North Carolina region (see Table 1), and 3 of the 14 species tested were previously reported to be SCB hosts (corn, yellow nutsedge, and peanut). Circular enclosures ( $3 \mathrm{~m}$ in diameter) made of sheet aluminum or fiber glass were set into the ground to provide a barrier of at least $30 \mathrm{~cm}$ above ground. Observations indicated that SCB were unable to climb up these surfaces. Noncrop species were transplanted from nearby sites into the enclosures. Crop species were seeded in the enclosures and allowed to grow for 2 to 3 weeks to minimize growth stage differences between crop and weed species. Five to ten plants of each species were grown in an enclosure. Duplicate enclosures were utilized for most species and studies on all species were repeated over 2 to 3 years. Ten male and 10 female field-collected SCB adults were released in each plot and observations made 3 to 4 times thereafter at weekly intervals on SCB feeding and plant damage. Subsamples of plants were removed from plots 1 to 3 weeks after infestation and examined for SCB eggs and larvae.

SCB adult feeding response was assessed qualitatively by ranking plant damage as low, medium, high, or nonexistent (Table 1). When comparing different plant species, this was not a precise method. However, because of the feeding habits of SCB adults (i.e., they insert their beak into the plant base and rasp out tissue), a direct measure (e.g., leaf areas consumed) was not possible. In our opinion, plant damage, although not precise, was sufficient to rank feeding response in a relative manner. Field observations of SCB feeding behavior gave additional evidence which supported the plant damage rankings.

Larval development was tested further by artificial infestation of pot-grown plants with a known number of SCB eggs. Five to 10 eggs per plant were placed around the base of plants (5 to 15 plants per species), just below the soil surface, to simulate SCB egg deposition. Four to 5 weeks after infestation, plants were dissected and examined for larval feeding damage and larvae. 


\section{Host Plant Effect on Adult Survival and Egg Maturation}

Adult SCB collected from volunteer corn in Tyrrell County, N.C., 18 to 19 September 1979, were held under moist conditions in clear plastic boxes, in the dark, at 5 to $10^{\circ} \mathrm{C}$ until 12 December, then placed outdoors in a wooded area, and covered with a light layer of leaf litter. On 22 April 1980, they were removed from woods and held at 5 to $10^{\circ} \mathrm{C}$ in the dark until 17 May. Adults surviving were sexed, divided into five groups, held in clear plastic boxes ( 34 by 17 by $8.5 \mathrm{~cm}$ ) at $27^{\circ} \mathrm{C}$, photoperiod LD 14:10, and fed sections of greenhousegrown Pennsylvania smartweed, Polygonum pensylvanicum L., common lambsquarters, Chenopodium album L., fall panicum, Panicum dichotomiflorum Michaux, yellow nutsedge, Cyperus esculentus L., and field corn, Zea mays L. (cv. Pioneer brand 3148). Because of the low numbers of SCB available, this study was unreplicated. Each container held 30 females and 38 males of SCB (except smartweed with 27 female and 33 male SCB). The smartweed and lambsquarters were field collected as cuttings and rooted in pots; sections used were cut from terminal growth. Yellow nutsedge and fall panicum were field collected as seedlings and transplanted into pots; the basal half of the plant was used. Corn was grown in pots from seed and the lower stalk portion of young plants (four- to eight-leaf stage, [Hanway 1966]) was used. An excess of plant parts was provided the SCB and changed 3 to 5 times a week.

When plant parts were changed, the number of eggs oviposited was determined by examining plant parts and the floor of the containers. Dead SCB were removed, sexed, and preserved in $70 \%$ ethanol for later dissection. Subsamples of live adults were removed from corn and nutsedge at intervals and preserved as above. Adult females were dissected to determine ovarial maturation; numbers of mature chorionated eggs present were counted.

\section{Adult and Larval Host Range}

\section{Results and Discussion}

During field studies from 1978 to 1980 , SCB adults were observed feeding on: Cyperus spp.; Pennsylvania smartweed; giant cane, Arundinaria gigantea (Walter) Muhlenberg; fall panicum; Scirpus cyperinus (L.) Kunth.; and corn. Numerous fall panicum plants were examined in cornfields infested with SCB, but no eggs or larvae of SCB were found. We observed immature SCB only in $C$. esculentus; corn, and $S$. cyperinus.

In August 1980, two teneral SCB adults were found in $S$. cyperinus stalks. This is a new larval host record of SCB. The plants were in a Tyrrell County, N.C., drainage ditch next to an SCB-infested cornfield. $S$. cyperinus plants sampled at two other sites near SCB populations on corn in Tyrrell County, and at TRS showed no evidence of SCB. We observed SCB adults feeding on $S$. cyperinus in the spring of 1980 at one site near an infested cornfield, although no immature SCB were found when this site was sampled in August 1980. $S$. cyperinus is widely distributed and abundant in eastern North Carolina (Radford et al. 1968), but its importance as an SCB host plant is unknown.
Although adults fed on most grass and broadleaf species in the field enclosure study, of the 14 species of plants tested, larval development occurred only with corn and yellow nutsedge (Table 1). Adults fed lightly on fall panicum, giant cane, giant foxtail (Setaria faberi Herrmann), kenaf (Hibiscus cannibinus L.), and Pennsylvania smartweed, although no eggs, larvae, or larval feeding damage was found. The absence of larval development on fall panicum is interesting because two other Panicum spp. have been reported as SCB hosts (Satterthwait 1931, Webster 1912). Broadleaf signalgrass, Brachiaria platyphylla (Griesebach) Nash was tested only by artificial infestation with SCB eggs, and no larvae were found on this species. Adults fed moderately on the four Sorghum spp. tested (Table 1), and some eggs but no larvae were found. No evidence of feeding or oviposition was observed on peanut, Arachis hypogaea L., or soybean, Glycine max (L.) Merrill, in the field plots; however, two larvae developed up to 2nd to 3rd instar on peanut when five eggs per pod were placed in the soil near seven developing pods. Webster (1912) reported SCB adults and larvae damaging peanut in Chowan County, N.C. Our field enclosure studies do not substantiate this, because adults never were observed to feed on peanut and neither eggs nor larvae were found in the plants. The results of the artificial infestation study probably are not applicable to the field because ovipositing adult SCB are not common at the time of peanut pod formation (Wright 1981). The absence of feeding signs in soybean is important as soybean is the major alternate crop in common corn rotations used in eastern North Carolina today.

\section{Host Plant Effect on Adult Survival and Egg Maturation}

Although there was rapid initial mortality of males on corn ( 5.0 days to $50 \%$ mortality), the overall survival of SCB was highest on corn, with survival on yellow nutsedge slightly lower. The other plants in decreasing order of SCB survival were Pennsylvania smartweed, fall panicum, and lambsquarters (Table 2).

Cartwright (1933) reported that overwintered SCB (eight males and eight females) held outdoors with access to water but not to food lived an average of 19 and 16 days ( 28 and 31 days maximum) for males and females, respectively. In our study, the combined average length of survival of male and female SCB fed smartweed, lambsquarters, or fall panicum was 21.0 and 20.5 days, respectively. Thus, these plants did not greatly extend the survival of SCB over that reported by Cartwright (1933) when SCB were held in the absence of food.

Mature eggs were found only in females fed corn or yellow nutsedge. Number of mature eggs per female ranged from 1 to 8 , with an average of 2.9 .

The absence of mature eggs and poor survival of SCB fed plant species other than corn and yellow nutsedge are further evidence of the restricted host range of this species. Although adults fed on other plant species in the laboratory and field, these plants did not allow egg maturation, nor did they support survival well. 
Table 1.-Field studies of adult and larval southern corn billbug (SCB) host range, Plymouth, N.C. 1978 to 1980

\begin{tabular}{|c|c|c|c|c|c|}
\hline \multicolumn{3}{|c|}{ Test plant } & \multicolumn{3}{|c|}{ SCB response } \\
\hline Family & $\begin{array}{l}\text { Common } \\
\text { name }\end{array}$ & Cultivar & $\begin{array}{c}\text { Adult } \\
\text { feeding }\end{array}$ & Oviposition $^{a}$ & $\begin{array}{c}\text { Larval } \\
\text { development }\end{array}$ \\
\hline Graminae & Field com & Pioneer brand 3535 & +++ & +++ & + \\
\hline Cyperaceae & Yellow nutsedge & - & +++ & +++ & + \\
\hline Graminae & Grain sorghume & Dekalb BR 45 + & ++ & + & - \\
\hline Graminae & Sudangrass $^{d}$ & NK Trudan-7 & ++ & + & - \\
\hline Graminae & Sudax ${ }^{e}$ & Funk 83F & ++ & + & - \\
\hline Graminae & Johnson grass' & - & $t+$ & + & - \\
\hline Graminae & Fall panicum & - & + & - & - \\
\hline Graminae & Giant foxtail & - & + & - & - \\
\hline Malvaceae & Kenaf & G 57 & + & - & - \\
\hline Graminae & Giant cane & - & + & - & - \\
\hline Polygonaceae & Pennsylvania smartweed & - & + & - & - \\
\hline Fabaceae & Peanut & Florigiant & - & - & - \\
\hline Fabaceae & Soybean & Forrest & - & - & - \\
\hline Graminae & Broadleaf signalgrass & - & $\longrightarrow$ & $\rightarrow$ & - \\
\hline
\end{tabular}

a +++ , High; ++ , medium; + , low; - , none.

${ }^{b}+$, Larvae able to complete development; -, larvae unable to complete development.

'Sorghum bicolor (L.) Moench.

¿Sorghum vulgare Persoon.

'Sudax is a grain sorghum $\times$ Sudangrass hybrid.

SSorghum halepense (L.) Persoon.

'Tested only for larval development by artificial infestation with SCB eggs.

Table 2.-Mortality of overwintered adult SCB held at $27^{\circ} \mathrm{C}$, photoperiod LD 14:10, and fed sections of five plant species grown in the greenhouse, 1986

\begin{tabular}{|c|c|c|c|c|}
\hline \multirow{3}{*}{ Food source } & \multicolumn{4}{|c|}{ Days to: } \\
\hline & \multicolumn{2}{|c|}{$\begin{array}{c}50 \% \\
\text { Mortality }\end{array}$} & \multicolumn{2}{|c|}{$\begin{array}{c}90 \% \\
\text { Mortality }\end{array}$} \\
\hline & Male & Female & Male & Female \\
\hline Corn & 5.0 & 49.5 & $>89$ & $>89$ \\
\hline Yellow nutsedge & 25.0 & 20.5 & $>89$ & $>89$ \\
\hline Pennsylvania smartweed & 21.8 & 22.2 & $>37$ & $>\mathbf{3 7}$ \\
\hline Fall panicum & 18.0 & 16.0 & 30.6 & 23.0 \\
\hline Common lambsquarters & 6.1 & 6.3 & 10.1 & 10.0 \\
\hline
\end{tabular}

aData based on 30 female and 38 male field-collected SCB, except for smartweed with 27 female and 33 male SCB.

These studies confirmed the reported narrow host range of SCB. None of the plants studied except corn, $S$. cyperinus and yellow nutsedge allowed SCB to complete larval development. Although adults fed on a wider range of hosts than larvae, three grass and broadleaf species (larval nonhosts) fed to adults did not allow egg maturation to occur, nor did they support long-term survival.

Thus crop rotation can continue to be recommended as an effective cultural control for SCB in eastern North Carolina. Rotation with broadleaf crops should not result in crop injury and should reduce SCB populations. Poor control of Cyperus spp. weeds in a field may reduce the efficacy of crop rotation by allowing SCB survival and reproduction.

\section{Acknowledgment}

We thank G. G. Kennedy, F. L. Gould, and G. C.
Rock for review of this manuscript, M. Rogerson, N. Whitehurst, and V. W. Modlin for technical assistance, and Frank Watson, Dept. of Botany, North Carolina State University, Raleigh, for identification of $S$. cyperinus.

We are grateful for partial financial support received from the Corn Producers Association of North Carolina and the National Crop Loss Design Committee, USDASEA.

\section{REFERENCES CITED}

Cartwright, O. L. 1933. Corn billbugs. Forty-Sixth Annu. Rep. S.C. Agric. Exp. Stn. pp. 72-74.

Hanway, J. J. 1966. How a corn plant develops. Iowa State Univ. Coop. Ext. Serv. Spec. Rep. No. 48.17 pp. 
Metcalf, Z. P. 1917. Biological investigation of Sphenophorus callosus Olivier (sic). N.C. Agric. Exp. Stn. Tech. Bull. 13. $123 \mathrm{pp}$.

Radford, A. E., H. E. Ahles, and C. R. Bell. 1968. Manual of the Vascular Flora of the Carolinas. University of North Carolina Press, Chapel Hill. 1183 pp.

Satterthwait, A. F. 1931. Key to known pupae of the genus Calendra, with host-plant and distribution notes. Ann. Entomol. Soc. Am. 24: 143-172.
1932. How to control billbugs destructive to cereal and forage crops. U.S. Dep. Agric. Farmers Bull. 1003. 22 pp.

Webster, F. M. 1912. The so-called "curlew bug." U.S. Dep. Agric. Bur. Entomol. Bull. 95. Part IV. pp. 53-71.

Wright, R. J. 1981. The biology and ecology of the southem com billbug in eastern North Carolina. Ph.D. thesis, North Carolina State University, Raleigh. 117 pp. 